increase that occurred was in chironomid larvae. The delay of 2 years between fertilization and benthic production requires more detailed investigation. There are two important stages: firstly, an increase in reproduction by the population to supply the increased numbers, and secondly, an increase in food requirement of this larger population. Thus fertilization will have different types of effect on the population of animals on the bottom, and to make the most rational use of fertilizers we need to know the relative importance of increased plant growth in increasing reproduction and in increasing food for the adult benthic animals. The general continuous addition of fertilizer could prove wasteful and uneconomic. In particular, a large increase in production of chironomids might seem too wasteful a form of production since these are not true members of the benthos.

To sum up, of the three factors mentioned at the beginning, predation, disease and food supply, the most obvious one, predation, is perhaps the simplest to consider. It is apparent that predatory organisms such as crabs and small round fish will have to be excluded from an enclosure. The second factor, disease, is likely to be more troublesome. So far we have identified one main source but there are probably several other parasitic infections which may be found in semi-enclosed areas and which could have as serious effects on the fish. Yet, finally, the most important factor is the food supply since for each $\mathrm{lb}$ of fish taken from the pond $6 \mathrm{lb}$ or more of food will need to be added. It is obvious that this poses the main economic problem. The provision of an outside supply of food such as fish offal, which is economic for more valuable species like rainbow trout, may not be economic for the less valuable marine fish such as plaice, or even sole. There could be practical difficulties during the large-scale production which is the basic reason for considering the more common commercial fish such as plaice or sole. At present we have insufficient knowledge to state the economics of a return to be gained from fertilization, but certainly this is the most interesting scientific and practical problem. It is possible that initial stocking densities may find sufficient food available naturally during the Ist year of life. It is also possible that the addition of fertilizer at this time would not show any benefit in increased food for about $\mathbf{I}$ or 2 years. But these two factors combined could permit an increasing supply of benthic food to become available to the fish as they grow in their 2 nd and $3^{\text {rd }}$ years, and this could provide a compatible programme of stocking and fertilization.

\title{
Engineering aspects of fish farming
}

\section{By W. Frazer, Department of Civil Engineering, University of Strathclyde, Glasgow}

\section{Introduction}

The civil engineer's part in a fish farming operation is to provide the means of holding fish within an area and maintaining a specified environment within this area. He also may be involved in arrangements for harvesting.

The raising or holding of freshwater species is an old established art and is practised throughout the world. In tropical areas growth rates are spectacular and there 25 (2) 4 
is no doubt that potential for a massive contribution to the world protein supplies lies in these areas. However, as I have said, fish farming up to the present has been more of an art than a science and it is only within the last few years that the work of Shelbourne and his colleagues has shown that the door is open to the possibilities of scientific stock raising such as selective breeding and hybridization.

Similarly, on the engineering side very little attention has been paid to management; for instance, at Arcachen near Bordeaux, there is a thriving fish farm raising mullet and bar. The ponds here were originally constructed as salt pans but it was soon observed that fish which entered the ponds thrived and the fish were more profitable than the extraction of salt.

In general, the capital cost of fish farms, with the possible exception of trout farms, is low, but with the growing need for protein and the increasing costs of hunting sea fish it appears that there is a strong case that quite high capital and operating costs may be economic.

As has been already stated, the concern of the civil engineer is to provide the means of holding fish and maintaining a specified environment.

The remit from the White Fish Authority to the Civil Engineering Department of the University of Strathclyde was to investigate the civil engineering problems likely to be associated with marine fish farming and the work was commenced by an investigation into possible sites. These sites can be classified as: (a) intertidal and shallow enclosures, (b) loch enclosures and (c) sites where the waste heat from power stations is available.

In late 1964 owing to the success of the hatching and rearing programme at Port Erin it was decided that a pilot farm should be established ready to receive metamorphosed plaice in August 1965. After a survey of many sites, an inlet on the north coast of Ardnamurchan, Sailean Dubh, was chosen for its biological and engineering suitability. Work was put in hand and with a great deal of effort the pond was ready to receive fish at the appointed time. Fortunately fine weather allowed the stocking to proceed without need for the elaborate transport arrangements which had been made in case weather prevented direct landing on the beach.

\section{Intertidal enclosures-Sailean Dubh}

The 5-acre pond at Sailean Dubh in Ardnamurchan, which was selected for the retention of fish on 25 March 1965 , was filled with sea water ready for the arrival of the first O-group plaice stock from Port Erin on 3 August 1965 .

Work commenced on the site in May 1965 , and the contractor was given 3 month to complete both sea walls on either side of a central island, and also to lay two pipelines for the diversion of sewage and fresh water.

Until the substantial completion of both sea walls, all work had to be carried out at low water and any concrete poured protected from scour by the incoming tide. Rock blasting was necessary to obtain a key for the toe of the sea walls, and this proved difficult owing to the extreme hardness of the rock, but work progressed very satisfactorily, until the discovery of a buried glacial channel under the north 
sea wall. This unfortunately delayed the programme and, despite night tidal working, the sea walls were not finally completed until 6 August 1965 .

However, since both the pipelines, the control plinths containing the 12 in diameter sea water sluice valves and the freshwater adjustable weirs were complete, and the sea walls constructed to $+\mathrm{r} 2 \cdot 0 \mathrm{ft}$ O.D. or above, it was possible to fill the pond on 2 August 1965. The only work completed subsequently was the completion of the sea walls, the laying of a tarmac surface to the access road to the south sea wall, and the provision of a hand-rail on the tops of both sea walls.

During the pond's operation in August and September, it became clear that the 6 in diameter diversion pipeline on the main stream was not adequate to deal with the torrential rain which occurred during this period. The pond was thus inundated with brown peaty water off the hill. Although freshwater weirs were incorporated in the sea walls for skimming off the surface, turbulence in the pond due to wind and waves caused the fresh water to mix with the pond's sea water, thereby reducing its salinity.

During the spring tide periods, by means of the sea sluices and weirs the pond was drained down to its minimum operational level $(+6 \cdot \circ \mathrm{ft}$ O.D.) and refilled at the subsequent high water. This is possible only during spring tides, about 6 days a fortnight.

At a site meeting on $5 / 6$ October 1965 , it was decided that further remedial work was required for the exclusion of fresh water from the pond. Although the University had acted as consultants during the initial contract, their research programme had been seriously curtailed by the design and supervisory work involved and it was decided to call on consultants to advise on the mode of dealing with the incursion of fresh water. They initially submitted a plan to construct a high dam to act as a flood storage reservoir for the main stream, and to build another dam at the pond's southern extremity to store the water from the pond's catchment, and to provide it with a small $\mathrm{I} 5$ in diameter outflow pipe. It was felt that the flooding of several acres of crofters' land by the formation of a high dam was undesirable, and eventually the accepted proposals for the diversion of the fresh water were the construction of a rockfill dam to create a freshwater pond at the southern end of the original pond, and to provide a large 36 in diameter outflow pipe to divert the water out to sea. Work on these projects will commence shortly.

During August and September measurements of the dissolved oxygen content of the pond water showed it to become very low 4-5 days after exchange of water during spring tides, and in some parts anaerobic conditions existed with the subsequent formation of $\mathrm{H}_{2} \mathrm{~S}$. Since the pond had been cleared of weed before inundation, it would appear that the sea bed was responsible to a great extent for the uptake of this dissolved oxygen. Some oxygen demand had been expected but complete stripping of the dissolved oxygen so quickly from the pond was unexpected. Undoubtedly a considerable portion of the loss would be due to the change from an intertidal regime to a sublittoral one, and after an initial period of inundation this demand would fall. Throughout the winter, daily monitoring of the sea's temperature and salinity has been carried out by the site staff, and water samples have been returned to the University once a fortnight for the analysis of nitrites, nitrates and phosphates. 
Conclusions from Ist year's research at Sailean Dubh. Although work is now in hand for the exclusion of fresh water from the pond at Ardtoe, it would appear that the salinity tolerance of plaice is greater than generally realized, since, when the marine biologists completed their census of stock in November, they found several plaice living quite happily in relatively fresh water. Though there could be a case for investigation into the salinity tolerance of plaice for the proper assessment of future sites, this may be obviated by the current work on plaice-flounder hybrids.

The dissolved oxygen content of the water must be considered, firstly due to stratification and secondly due to uptake by the bottom sediments. In order to rectify stratification (especially during neap tides) some form of mechanical overturn is necessary to mix the water. As regards oxygen uptake of the bottom sediments this could initially, before stocking the pond, be ameliorated by creating recirculation within the pond by changing the water constantly during a spring tide cycle. However, once fertilization experiments are under way, a water change would not be desirable and mechanical methods of overturn, aero-hydraulic guns or aqualators are being considered. Future work, however, will provide a period of readjustment of the flora and fauna before restocking with fish.

The use of concrete for forming sea walls etc., although often the simplest form of construction, should be completed as long as possible before the introduction of fish stock, to enable the leaching action of the sea water on the concrete to be complete before permanently filling the pond.

\section{Sites for sea loch enclosures}

The term sea loch enclosure is used to describe a body of water with appreciable volume below low water, whose connexion with the open sea can be made impenetrable to fish and also as far as possible to predators. Both from the point of view of construction of a barrier which would allow free exchange of water between the enclosure and the open sea, and also from the point of view of nutrient fertilization experiments, a cotidal range chart for spring and neap tides of the west coast of Scotland including the western isles has been constructed. It must be pointed out, however, that under certain circumstances a small tidal range could be coupled with low oxygen levels.

Several sites have now been investigated with a view to finding suitable sites of I0-50 acres in extent, one with a mean depth of $2-3$ fathoms and another with a mean depth of 5-10 fathoms, together with further work on intertidal sites.

\section{Barriers to fish}

This investigation, which is primarily a review, has now progressed to the state where site investigations both of permeable and impermeable construction are of value. In the latter context a visit to see how the French have constructed two fish farms in the Gironde was made last year and a report issued (Report $\mathrm{HO}-65-12$ ) on their work and its relevance to our own problem.

With regard to permeable barriers, this has been carried out under four headings. 
Mesh or net screens. A visit has already been made to the Boom Defence Department of the Royal Navy to examine their anti-torpedo type of nets and to see their method of replacement. The type of anti-torpedo net used for sealing main loch entrances would appear too heavy for our type of work, but the sections used to seal the intertidal stretches look very promising and their rigidity in the centre of small channels is now under investigation. Fish stake nets are also being examined since any net system would require to be a combination of a heavy sea net against predators and a light fish retention net.

Electrical. Arrangements are now under way to visit the electrical barrier used to prevent fish entering the tailrace at Inverawe Power Station in Perthshire, Scotland.

Sonic and ultrasonic. Very little relevant information has been found to date about reaction of fish to sound and assistance of the biologists is requested.

Hydraulics and pneumatic. Both of these create vertical water currents and the reaction of fish to these requires investigation.

\section{Power stations}

A number of power stations were visited in September 1965 with $\mathrm{Mr}$ J. E. Shelbourne in order to appraise the merits of the various sites. The results were rather inconclusive owing to variability of power station operation and the scarcity of information on chlorination residuals. Some general observations were, however, possible.

West coast stations have a much smaller annual temperature fluctuation than east coast stations. On the east coast the stations visited were on the open coast where stormy conditions often throw a considerable amount of sediment into suspension.

It was, therefore, decided that the biologists would carry out probe experiments at Carmarthen Bay and also at Hunterston for a period of at least 3 months. At the conclusion of this period, a decision will be made as to whether, and at what station, two to three tanks $49 \mathrm{ft} \times 25 \mathrm{ft} \times 3 \mathrm{ft}$ deep, would be placed in order to carry out further work. Once these tanks are in operation, tests would be carried out to determine flow patterns and heat losses within the tanks under various conditions.

\section{Sea fish culture in Britain}

By J. E. Shelbourne and C. E. NASH, White Fish Authority, Port Erin, Isle of Man

A study of the biological, engineering and economic implications of marine fish culture on an industrial scale is being made by the White Fish Authority, in association with the Ministry of Agriculture, Fisheries and Food, and the Civil Engineering department of the University of Strathclyde.

\section{Fish hatching programmes}

Renewed interest in sea fish farming has been stimulated by the discovery that flat-fish are not as difficult to rear as originally thought. In 1962, after several years' work on the special requirements of plaice eggs and larvae in the hatchery, $66 \%$ 